\title{
CANADIAN WOMEN AND THE (RE)PRODUCTION OF WOMEN IN AFGHANISTAN
}

\author{
by
}

Melanie Butler

A THESIS SUBMITTED IN PARTIAL FULFILLMENT OF THE REQUIREMENTS FOR THE DEGREE OF

MASTER OF ARTS

in

The Faculty of Graduate Studies

(Political Science)

THE UNIVERSITY OF BRITISH COLUMBIA

(Vancouver)

August 2008

(C) Melanie Butler, 2008 
ABSTRACT

Canadian women have been at the forefront of the international movement for women's rights in Afghanistan since the rise of the Taliban in the late 1990s. Focusing on the prominent group Canadian Women for Women in Afghanistan (CW4WAfghan), this paper looks at the role its advocacy assumes in the context of the "War on Terror". In Canada as in the United States, government agencies have justified the military invasion of Afghanistan by revitalizing the oppressed Muslim woman as a medium through which narratives of East versus West are performed. While CW4WAfghan attempt to challenge dominant narratives of Afghan women, they ultimately reinforce and naturalize the Orientalist logic on which the War on Terror operates, even helping to disseminate it through the Canadian school system. Drawing on post-colonial feminist theory, this paper highlights the implications of CW4WAfghan's Orientalist discourse on women's rights, and tackles the difficult question of how feminists can show solidarity with Afghan women without adhering to the oppressive narratives that permeate today's political climate. It is only by employing alternative models that contextualize the situation of Afghan women in relation, rather than in opposition, to our own, that feminists can begin to subvert the mutually reinforcing narratives that sustain imperialist violence and women's subordination. 


\section{TABLE OF CONTENTS}

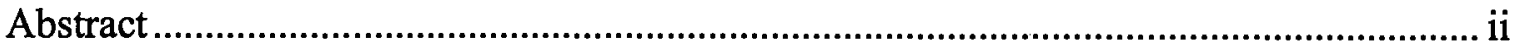

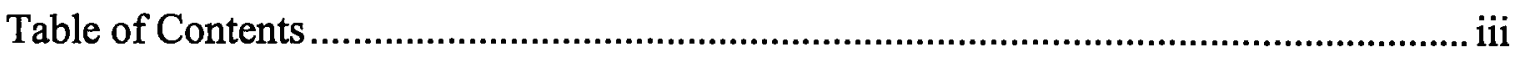

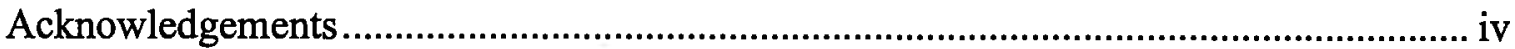

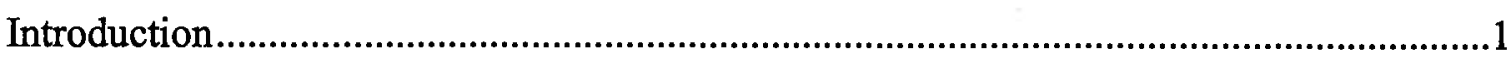

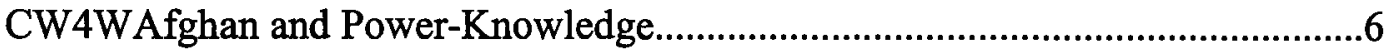

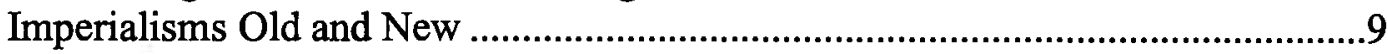

Reifying the Individual Subject: Narratives of Personal Experience ...............................13

Peddlers and Peacekeepers: National Narratives of East and West...................................22

Re-writing the War Story: Alternative Narratives ............................................................31

Canadian Students as Global Citizens: Orientalism in the Classroom? ............................33

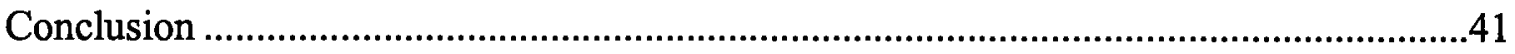






\section{ACKNOWLEDGEMENTS}

I would like to thank my supervisor, Dr. Lisa Sundstrom, for encouraging and guiding my pursuit of this topic, and for always leaving her office door open. I am also extremely grateful to Dr. Bruce Baum for his thoughtful and valuable feedback, and to Carly Butler and Rebecca Collard for their meticulous readings and edits. Finally, I wish to extend my sincere gratitude to Dr. Sunera Thobani, Solanna Anderson, Amany AlSayyed and Manneke Budiman for inspiring and contributing to many of the ideas on which this paper was built. 


\section{INTRODUCTION}

When the occupation of Afghanistan by American forces can be justified as necessary in order to save Afghan women from the Taliban, feminists must necessarily pay attention to how their demands serve the interests of imperialism and white supremacy.

-Sherene Razack, University of Toronto (2007: 7)

Canadian women should keep the public debates focused on the women and girls of Afghanistan... and must also fight the stubborn attitude that Afghan women should be simply left to sort out their problems by themselves.

-Sally Armstrong, Canadian Women for Women in Afghanistan (Glavin 2007)

In the late 1990s, news that Afghanistan was being controlled by one of the most misogynist regimes the world had ever known—the Taliban—prompted women's groups across the globe to demand that its brutal reign be terminated by whatever means necessary. This sentiment took on new meaning, however, in the aftermath of 9/11. Faced with the prospect of war, feminists were divided over whether the potential of liberating Afghan women from the Taliban outweighed the negative consequences that war always has on women's lives. As Afghan women continue to struggle under the Taliban and foreign military forces, the idea of a war for women's liberation has proven to be a false choice, rooted in discourse that remains one of the most powerful instruments of women's subordination today.

A fundamental implication of Michel Foucault's decisive hyphenation of power and knowledge has been the recognition that language and discourse are not merely subservient to "hard politics", but are themselves constructions of power with tangible consequences. Expanding Foucault's work beyond the European context, Edward Said, for example, crucially demonstrated the implications of power-knowledge used by imperial nations in constructing East and West, pointing out that knowledge about "The 
Orient" cannot be separated from the political and military dimensions of colonial power (Said 1978). As Orientalist tropes are reinvented in the context of the War on Terror, examining Orientalism as a discourse has perhaps become even more important to an understanding of contemporary American imperialism than it was in Said's time to an understanding of "the enormously systematic discipline by which European culture was able to manage - and even produce— the Orient politically, sociologically, militarily, ideologically, scientifically, and imaginatively during the post-Enlightenment period" (ibid: 3 ). ${ }^{1}$ At the same time, the fiercely reinvigorated Orientalist trope of the veiled Muslim Woman-oppressed, seductive, and threatening —and her enduring ability to provide justification for imperialist violence, point to the limitations of Said's analysis, bringing into question his "relegation of questions of gender and sexuality to a subdomain of Orientalist discourse" (Yegenoglu 1998: 10). ${ }^{2}$

The work of feminist scholars such as Meyda Yegenoglu, whose reading of Orientalism provides the cornerstone of this analysis, advances on Foucault and Said's work to demonstrate how Orientalist discourse constructs not only colonial, but also gendered, racialized, and otherwise hierarchically-ordered subjects. These various manifestations not only help explain Orientalism's ability to endure beyond the historical period of colonialism, but also provide insight into the specific consequences of the narratives of Afghan women that have proliferated since 9/11. As Miriam Cooke argues,

\footnotetext{
${ }^{1}$ My definition of imperialism, borrowed from Edward Said, refers to "the practice, the theory, and the attitudes of a dominating metropolitan centre ruling a distant territory" (1994: 8); whereas colonialism refers to "the implanting of settlements on distant territory" (ibid). I use the term neo-imperialism to refer to contemporary power relationships and imperialist attitudes that tend to result more from economic and political domination, rather than from territorial conquest, as is (arguably) the case in Canada's relationship to Afghanistan in the War on Terror.

2 Although I do not attempt within this paper to do justice to the copious discourse surrounding the veil, I encourage readers to consult Yegenoglu (1998: 39-67) for a particularly brilliant discussion of the veil in Orientalist discourse.
} 
the official state-sanctioned "War Story" of why we go to war and how wars are won gives order to chaotic circumstances by appealing to constructed binaries - not only West and East as friend and foe, but also notions of homeland and front, combatant and civilian, victory and defeat, war and peace (1996: 15). These clean distinctions depend on equally dichotomous conceptions of gender including traditional notions of masculinity and femininity such as "women's need for protection as the reason men must fight" (ibid). As this gendered narrative is employed in the War on Terror, it reveals a patriarchal logic that, as Iris Marion Young describes, "puts those protected, paradigmatically women and children, in a subordinate position of dependence and obedience" (Young 2003: 2). This is inextricably bound up with narratives of race and nation that help legitimize military dominance abroad, and are manifested domestically in the subordination of women at the level of both the state and the family (2003). The narrative of the Afghan woman emerges today through this perilous space, where imperialist constructions of knowledge intersect with discourses of gender and sexuality to create the "dual oppressions" of "gendered Islamophobia" (Zine 2004; cited in Zine 2006).

Feminists navigating the War on Terror's difficult terrain must be sharply aware of the productive power of dominant discourses, and their ubiquitous ability to emerge within seemingly subversive texts, including those of feminist discourse itself. In their bid to help Afghan women, however, some feminist groups have failed to distance themselves from the discursive mechanisms that manufacture consent for women's oppression in the name of Empire. Building on Krista Hunt's analysis of feminist complicity in the War on Terror (Hunt 2006), this essay draws attention to Canadian 
feminists' role in (re)producing neo-imperialist narratives of Afghan women. Focusing specifically on the NGO Canadian Women for Women in Afghanistan (CW4WAfghan), it shows how their use of feminist rhetoric and personal first-hand narratives, together with national narratives of Canada as a custodian of human rights, add to the productive power of the Orientalist tropes they invoke.

If within Canada, constructions of Afghan women remain one of the most powerful means by which knowledge about the "War on Terror" is produced, CW4WAfghan are among the most active and powerful disseminators of such knowledge. CW4WAfghan express the importance of this role in their twofold mandate:

1) to raise awareness in Canada of the need to secure and protect human rights and opportunities for Afghan women and, 2) to support the empowerment efforts of Afghan women in education, health care and skills development (CW4WAfghan 2008a).

By explicitly focusing on how the second half of this mandate is pursued, my aim is not to discredit what CW4WAfghan may have accomplished in Afghanistan, but rather, to see how this work might be undermined by becoming part of the War on Terror's neoimperialist project of knowledge construction. My choice of focus thus stems from an affinity with CW4WAfghan's stated aim, but concern for the problems their strategies present in terms of their own goals and those of Canadian feminists in general.

Historically, Western feminists have played an integral role in colonization, championing liberal values as a means of "saving" their oppressed sisters from backwards societies. In light of the challenge this history promotes for women's organizing today, post-colonial feminists are approaching transnational solidarity by looking inward, attempting to excavate dominant narratives of gender, religion, and race from feminist discourse. As Gayatri Spivak asserts, the first step in confronting 
marginalized people such as Afghan women "is not to represent (vertreten) them but to learn to represent ourselves" (Spivak 1988: 288-9). By explicitly focusing on CW4WAfghan's discourse within Canada, I aim to take up this task of selfrepresentation, shifting the focus of knowledge produced in the War on Terror from East to West. Of CW4WAfghan's many approaches to educating Canadians about Afghanistan, I give special attention to their teachers' resource kits, which have been incorporated into the Canadian school system for students in grades 4-12. With its aim of moving students to action, this resource offers a particularly prescient example of CW4WAfghan's productive power in constructing knowledge about Afghanistan in the West, as well as Canadian feminists' specific contribution to the neo-imperialist discourse of the War on Terror.

While problematizing CW4WAfghan's representations of Afghan women, I also look at how anti-imperialist and anti-racist feminists are challenging dominant discourse by contextualizing the situations of Afghan women in relation to their own, rather than through the oppositional logic of Orientalism. Drawing particularly on Chandra Talpade Mohanty's comparative or "feminist solidarity" model of scholarship, I point to some ways that CW4WAfghan's educational resources could be modified in order to disrupt Orientalist representations of Afghan women as objects of knowledge, and to allow students to think critically about notions of gender, national identity, human rights, and war. My goal here is to acknowledge not only the complex ways in which Afghan women continue to be constructed by Western feminists, but also to address the dangers of trying to work with Afghan women while leaving these constructions and the assumptions they produce intact. Thus, although this paper is primarily an analysis of 
CW4WAfghan's discourse in Canada, it can also be seen to have implications for CW4WAfghan's projects abroad, offering relevance both to studies of discourse being used in the War on Terror, and to feminists-including those within CW4WAfghanseeking to understand challenges to transnational feminist organizing and women's empowerment worldwide.

\section{CW4WAfghan and Power-Knowledge}

The stories of Afghan women written by CW4WAfghan members Sally Armstrong, an international journalist and filmmaker, and Deborah Ellis, an award-winning novelist, are often cited as being the first in North America to bring awareness to the plight of Afghan women living under the Taliban (CW4WAfghan 2008b). Now with 15 chapters across Canada, expenditures of over $\$ 2,000,000$ (CW4WAfghan 2008a) and high-profile members such as Afghan Independent Human Rights Chair Dr. Sima Samar, CW4WAfghan have established themselves as the Canadian authority on Afghan women. They use their knowledge to provide the Canadian government with policy advice and gendered analyses of the situation in Afghanistan (CW4WAfghan 2008b: 6), as well as to defend Canada's military occupation of the country, endorsing the "War on Terror" as a necessary measure for providing security and development assistance to Afghan women (ibid: 7; Reicher and Oates, 2006; Oates 2007). CW4WAfghan pursue their advocacy role through public speaking engagements, Afghanistan-themed cultural events, and the distribution of informational bulletins about Afghanistan and Afghan women to Canadian newspapers and schools (CW4WAfghan 2008a). In addition to creating resource kits for Canadian teachers, CW4WAfghan are also involved in training teachers in Afghanistan (Government of Canada 2008). 
In terms of their visibility as a national feminist organization and their vocal support of the War on Terror, ${ }^{3}$ CW4WAfghan's status parallels that of the Feminist Majority Foundation (FMF) and their role as "embedded feminists" in the United States (Hunt 2006). Coined by Krista Hunt, 'embedded feminism' broadly refers to "the incorporation of feminist discourse and feminist activists into political projects that claim to serve the interests of women but ultimately subordinate and/or subvert that goal" (Hunt 2006: 53). Drawing on the US Department of Defense (DOD) policy of embedded media, Hunt argues that the Bush administration has embedded feminism to promote the war in Afghanistan as a "civilizing mission" that would liberate women (Hunt 2006: 5253). Like the FMF, CW4WAfghan has been organizing on behalf of Afghan women's rights since the late 1990s, and by supporting the invasion of Afghanistan in 2001, added weight to their government's ability to justify the war on humanitarian grounds. The idea they generate of CW4WAfghan working alongside and being protected by the Canadian military literally embodies the US DOD's policy of having media who "live, work, and travel as part of the units with which they are embedded" (US DOD, as cited in Hunt 2006: 52). By positioning themselves as the authoritative voice of Afghan women and endorsing the Canadian government's mission in Afghanistan, CW4WAfghan help insulate their government's policies from the criticisms of feminists who see it as a war on—not for-women's rights, and the observations of human rights organizations who testify that women's situation has not improved since the Taliban was in power, but has in many ways grown worse (Farhoumand-Sims 2007: 650; Hunt 2006: 64-65; Zia-Zarifi 2004).

\footnotetext{
${ }^{3}$ The extent of this support is perhaps best symbolized by a recent debate on the proposition: "The Canadian Military Should Leave Afghanistan at Once", in which CW4WAfghan vice-president Lauryn
} 
Despite the many similarities between CW4WAfghan and the FMF, CW4WAfghan's defense of government policies seems to exemplify a different dynamic of embeddedness than that at work in the American case. In contrast to what Hunt outlines as the Bush administration's "strategy of co-opting women's rights discourse and mobilizing the FMF to support the war on terror"(53), in the Canadian case, it is CW4WAfghan who appear to be making up for their government's ineffective use of this strategy, soliciting the government to co-opt their discourse in order to legitimize Canada's participation in the war-and therefore their own support for that participation. In a recent newsletter, for example, CW4WAfghan vice-president Lauryn Oates praises a government-issued report on Canada's future role in Afghanistan, while at the same time acknowledging the report's complete lack of attention to women's rights (CW4WAfghan 2008b: 6). ${ }^{4}$ Rather than condemning the report—or Canada's role in Afghanistan-Oates offers on behalf of her organization "to further share our insights and analysis regarding gender in Afghanistan" with the panel in charge of the report (ibid). This dynamic is echoed in other press statements, in which CW4WAfghan members attempt to combat "disturbing misinformation here in Canada that sees us as having 'invaded' Afghanistan or being an 'occupying force"' (CW4WAfghan 2008b), urging media to emphasize Canada's "security" role over their "military" one (Reicher and Oates 2006), and to focus more attention on how the Canadian government is improving Afghan women's lives (Oates 2006).

Oates' represented the negative (Oates and O'Keefe 2008). See also Reicher and Oates, 2006; Oates 2007. ${ }^{4}$ The "Manley report" also received widespread criticism in Canada from religious groups (Group of 78 et al. 2008; The Canadian Council of Churches 2008), intellectuals (Valpy 2008; Staples 2008), and even development organizations (World Vision Canada 2008). 
CW4WAfghan's struggle to link its government's motives in Afghanistan to a concern for women's rights is perhaps understandable in light of its reliance on government resources. CW4WAfghan regularly receives grants from the Canadian International Development Agency (CIDA), the aid-based branch of the Canadian government. CIDA funds CW4WAfghan's educational/ advocacy work within Canada (CW4WAfghan 2008a), and last March, donated \$500,000 to CW4WAfghan's “Excelrate Education Initiative" which will be used to train teachers in Kabul province (Government of Canada 2008). CW4WAfghan is also sponsored by Rights and Democracy, ${ }^{5}$ a CIDA-funded organization established by the Canadian parliament in 1988, aimed at providing a bridge between government officials and NGOs (CW4WAfghan 2008a: Projects and Project Partners). In addition to funding, Rights \& Democracy staff have helped CW4WAfghan members with skills-development, networking, and other resources, particularly through their Women's Rights in Afghanistan Fund (CW4WAfghan 2005: 12).

\section{Imperialisms Old and New}

The most frightening thing about imperialism, its long-term toxic effect, what secures it, what cements it, is the benevolent self-representation of the imperialist as saviour. (Spivak 1999: 54)

Each age and society re-creates its "Others" (Said 1978: 332)

As Krista Hunt points out, embedded feminism is by no means a new phenomenon, but has historical precedent in earlier nationalist and colonialist projects (2006: 53). These projects not only subordinated feminist goals to serve their own interests, but also jeopardized future women's organizing by implicating feminism in the

\footnotetext{
${ }^{5}$ Also known as the International Centre for Human Rights and Democratic Development.
} 
patriarchal logic of empire. The history of embedded feminism remains a barrier for women in colonized countries who are reluctant to align themselves with the ideology of their oppressors, and for transnational feminism in general, as unequal power relations between women continue to erode the delicate line between solidarity and cultural imperialism. One of the most pressing tasks of contemporary feminists is thus to extract our ideology from the imperialist discourses and practices within which it has become embedded. The discursive mechanisms on which neo-imperialism rely are not always evident, however, and can be particularly difficult to distinguish when they are buried within the trappings of feminism, which, "as a historically humanist project...has often been imagined as inherently egalitarian and inherently nonracist" (Srivastava 2005: 36). It is only by overturning such assumptions that we can begin to understand the power with which feminism imbues oppressive discourses such as imperialism.

According to Said, the power of Orientalism to survive throughout history is due largely to its "citationary nature" (1978:222), the process by which Orientalist texts confirm the body of knowledge they reference through their constant articulation and rearticulation of its discourse. As with other types of knowledge and identity, the discourse of Orientalism is not fixed, but must be constantly produced, through a system akin to what Judith Butler describes as "performativity": "that reiterative and citational practice by which discourse produces the effects that it names" (Butler 1993: 2). Although Orientalist texts may contest or correct the particular conceptions of the Orient they reference, in doing so they diversify, expand, and thus reproduce the grand performance of constructing (knowledge about) the "Orient", rather than challenging the unity and hegemony of Orientalist discourse itself (Yegenoglu 1998: 71). Feminist texts 
play a special role in this complex process, imbuing Orientalism with an assumed moral authority and compatibility with women's rights. The inconsistencies and contradictions revealed in this difficult negotiation give the appearance of debate, and even rejection of certain ideas, rejuvenating and repairing the master narrative to which they belong. It is these cracks in discourse that require special attention, however, for as Yegenoglu asserts, "if it is citationality that is essential in the sustenance of colonial discourse, it at the same time constitutes the possibility of its subversion and displacement" (ibid: 38 ).

At the heart of the relationship between feminism and imperialism is an Orientalist logic that posits Western women as exemplary and emancipated in relation to "Other" (Afro-Asian/colonized) women, thereby charging the former with the responsibility of saving the latter from their backwards (i.e. Muslim), uncivilized cultures. Evident in this "gendered logic of empire" (Cooke 2002: 485) is the way in which different systems of oppression interlock: just as "class exploitation could not be accomplished without gender and racial hierarchies... imperialism could not function without class exploitation, heterosexism, and so on" (Fellows and Razack 1998:1). Significantly, this meant that early feminism was dependent on the same systems of oppression that buttressed imperialism. As Antoinette Burton describes, for example, British feminists drew on dominant notions of white, middle-class women as the moral vanguards of society to justify both their demands for suffrage, and their participation in colonialism (Burton, 1992). By insisting on their racial superiority over colonized men, British women gained entry into a nation where they were not yet considered citizens, and positioned themselves as the appropriate candidates for the mission of civilizing colonized women (ibid). As Yegenoglu describes, such missions facilitated a largely 
imaginary form of emancipation that actually hindered the fight for women's rights, as for instance, "by thinking of themselves as all powerful and free vis-à-vis Egyptian women, Western women could avoid confronting their own oppression at home" (1998: 106). By examining how CW4WAfghan conceptualize themselves vis-à-vis their Afghan counterparts, we can see how contemporary embedded feminism both adheres to and departs from the historical relationship between feminism and imperialism, rejuvenating Orientalism as a neo-imperialist discourse. 


\section{REIFYING THE INDIVIDUAL SUBJECT: NARRATIVES OF PERSONAL EXPERIENCE}

CW4WAfghan's emphasis on listening to Afghan women and allowing them to determine their own needs reveals a departure from the colonial approach of using Western norms and standards of law, education, and religion as a means of "emancipating" women. Stressing that Afghan women "are the best authority for assessing their own needs", CW4WAfghan's rhetoric rejects "the often predominant perception that they are victims and that only external agents can adequately dictate what assistance should be provided for them" (CW4WAfghan 2005b:6). CW4WAfghan frame their approach as helping Afghan women help themselves, "assisting Afghan women in their struggles to end their oppression" by "partnering" with grass-roots groups within Afghanistan run by or for women (ibid). Emphasizing their credibility as a grassroots transnational network, members often draw on personal experiences to testify to the success of their projects or to lend urgency to their cause. These range from stories of Canadian members being enlightened and empowered by helping others, to expressions of gratitude and appreciation from Afghan people and painful recollections of Afghan women's oppression relayed to or witnessed by CW4WAfghan members.

The narratives of women's personal experiences that characterize CW4WAfghan's discourse evoke contemporary social movement, particularly feminist, practice, that typically sets itself up against the oppressive mechanisms of imperialism. Models of consciousness-raising and anti-discrimination education, for example, have traditionally used story-telling as a means of understanding oppression, challenging hegemonic discourse, and giving voice to marginalized groups. These models operate on the belief that "the personal is political", meaning that "talking about experience and 
emotion is seen as not simply a vehicle for self- disclosure, but as necessary for generating knowledge and strategy for social change" (Srivastava and Francis 2006: 282). CW4WAfghan's teaching module exemplifies this goal by encouraging students to "identify with the plight of the Afghan people" through role-playing exercises that represent "real situations that Afghan people have actually experienced" (CW4WAfghan 2008d). The emotionally-charged stories of Afghan women's suffering and progress that are often the focus of CW4WAfghan's public speeches and newsletters seek a similar effect, evoking a "very deep human connection" that they credit with moving audiences to action (CW4WAfghan 2008b : 2).

In addition to consciousness-raising, CW4WAfghan's use of personal experience and story-telling reveals a desire to legitimize the organization's policies and politics. In situations where their authority to speak on behalf of Afghan women is contested, such as in debates about the War on Terror, CW4WAfghan members position themselves as native informants of Afghanistan, citing their "first-hand experience" working with Afghan women as evidence of their authenticity (Oates 2008). In their newsletters and media correspondence, CW4WAfghan executive members make a point of referring to their time spent in Afghanistan, (CW4WAfghan 2008c) giving personal accounts of the impact that Canadians have in rebuilding the country. Revealing a rupture in this positioning, CW4WAfghan members sometimes even place their truth claims above those of Afghan women or groups with whom they disagree politically, such as the Afghan MP Malalai Joya, the Revolutionary Association of Women of Afghanistan (RAWA), and Humanitarian Assistance for the Women and Children of Afghanistan 
(HAWCA). In contrast to CW4WAfghan's nameless multitude of "Afghan colleagues", 6 these Afghan activists have stressed that democracy can only be realized through an "uprising of the Afghan nation" (RAWA 2001), and have accused the US and its allies of using the Taliban as an "excuse to stay in Afghanistan and work towards the realization of its economical, political and strategic interests in the region" (RAWA 2007). ${ }^{7}$ Refusing to take such views seriously, CW4WAfghan wield their stamped passports like wild cards, suggesting that those who dare challenge them "go see for themselves what life is really like in Afghanistan" (Oates 2008).

Given that Afghanistan is one of the most dangerous - and expensive-places to visit in the world, CW4WAfghan's suggestion is more likely an attempt to close down debate than to encourage tourism in the region. ${ }^{8}$ In this context, the personal becomes a convenient way of evading the political, lending authority to hegemonic voices. As Joan Scott points out, "when experience is taken as the origin of knowledge, the vision of the

\footnotetext{
${ }^{6}$ While it is possible that CW4WAfghan chooses not to mention names for reasons of confidentiality and security, this explanation is never given in cases where they refer only to their sources only as "Afghan colleagues". It is also unlikely to be necessary in most cases, given the high profile of the projects they fund in Afghanistan, and their endorsement by both the Canadian and Afghan government. In addition, this would not explain why the Afghan women pictured in their newsletters are rarely named (see for example CW4WAfghan 2008c:7).

${ }^{7}$ See also HAWCA 2003; Hunt 2006: 60.

${ }^{8}$ Interestingly, this is precisely the strategy used by members of Canada's governing party-who are also in the small minority of Canadians with the means of traveling to Afghanistan - to justify their presence in the country. For example, in a parliamentary debate over Canada's mission in Afghanistan last February, Minister of National Defence Peter MacKay closed by noting his many opportunities to visit Afghanistan while occupying the post, and asking to share with the House of Commons "a very personal experience" that had occurred during his last visit. Describing how "proud and overjoyed" Afghan children were upon receiving a delivery of school supplies prepared in Ottawa, he singled out one little girl as particularly memorable on account of her "stunning green eyes." In those eyes, MacKay claimed "I could see in convincing personal terms that the work we were doing was having an impact and that our continued presence was necessary" (emphasis added), adding that her face provided "more powerful testimony to the value of our efforts, above and beyond the statistics, the NATO discussions, the reports and the commentary." When challenged by a member of the opposition to comment on expressions of the children who had lost their families and lives to NATO bombs, MacKay's only rebuttal was to call his opponent a pessimist, and to offer the unassailable observation "He was not there. He did not see the young girl's face. He did not see the look in these people's eyes and their optimism for the future" (House of Commons:
} 1210-1255). 
individual subject (the person who had the experience or the historian who recounts it) becomes the bedrock of evidence on which explanation is built. Questions about the constructed nature of experience... are left aside" (Scott 1991: 777). By deliberately attempting to mask the problems that are always associated with representation, ${ }^{9}$ and the inconsistencies that inevitably arise within categories of experience, CW4WAfghan's use of personal anecdotes both confirms and conceals their own ideology. Reproducing the oppressive gesture of imperialist feminism, their homogenous image of Afghan women reduces them to the role of "generalized native informants", who Spivak asserts, "sometimes appear in the Sunday supplements of national journals, mouthing for us the answers that we want to hear as our confirmation of the world" (1999: 342).

In contrast to the goal of consciousness-raising, postcolonial feminists show how the valorization of women's experiences as irreducible ground for analysis evokes a liberal individualist framework that can function to erase the political and social context in which oppression is created (Khan 2001; Scott 1991, Srivastava and Francis 2006). Illustrating how this effect is produced, Shahnaz Khan targets Sally Armstrong's "Veiled threat", the story of an Afghan woman living under Taliban rule. ${ }^{10}$ Carefully analyzing passages in which Fatana, through Armstrong, likens life inside a burqa to imprisonment, Khan demonstrates how Armstrong "reduces oppression to the subjective psychological

\footnotetext{
${ }^{9}$ Spivak, for example, is careful to specify that it is not only representations of others that are problematic, but also the self-representations associated with identity politics, which attribute an inherent virtue and comprehensiveness to the "native's point of view" (Spivak, 1993-1994).

${ }^{10}$ This particular article, which was published in the Canadian Homemaker's magazine in 1997, is significant to an analysis of CW4WAfghan's discourse not only because it demonstrates the tone of many of Armstrong's and other members' articles and speeches, but also because it is often cited by CW4WAfghan members as a catalyst for starting or joining the group (see, for example, CW4WAfghan 1999: 1). While Armstrong's article has been criticized elsewhere for its overt ethnocentrism (Currier 2005; Zalman 2003) Khan's review stands out because of its eloquent connection of Armstrong's "west as best" (Khan 2001: 6) rhetoric with her employment of a liberal individualist framework that is particularly apparent throughout CW4WAfghan's discourse.
} 
state of feeling oppressed" (2001: 6). By way of explanation, Armstrong zeroes in on the Taliban, adopting a "micro-focus" that minimizes the role of the United States in creating the conditions of Fatana's oppression (Khan 2001). Absent from her account is any consideration of how the US helped bring the Taliban to power, why Muslim women might choose to "shroud" themselves in "hideous body bags" (Armstrong 1997), and in short, "the unequal relations which have created and reinforced particular interpretations of Fatana's story" (ibid), providing individuals like Armstrong with a monopoly on her truth.

CW4WAfghan's informative reports follow Armstrong's narrative formula, ${ }^{11}$ buttressing the shock and awe of Afghan women's suffering with selective historical and political explanation, while carefully refraining from implicating the power dynamics that sustain Canadian women's privilege to speak on Afghan women's behalf. In a recent newsletter, Armstrong describes the "cloud of fear" that hangs over the population of Afghanistan: a "fear of bombs, of suicide bombers, of corruption, of schools being burned, of teachers being beheaded, of government incompetence" (CW4WAfghan 2008b: 6). Not only does Armstrong fail to acknowledge that it is her government, with CW4WAfghan's support, that has helped pay for and drop those bombs, bring to power the corrupt and incompetent government officials, and instigate the insurgency and violence that plagues the country, she then goes on to conclude that more than any of these horrific realities, what Afghans fear most is the prospect of "being abandoned by the international community" (ibid: 7). To support her argument, Armstrong tells the story of a young Afghan woman who was facing death threats from her family for 
marrying someone outside her tribe. Turning this horror story into a success story of Western triumph, Armstrong notes that "although old tribal laws still prevail", the woman was able to seek help in Afghanistan by appealing to the Human Rights Commission (CW4WAfghan 2008b: 2).

As Joan Scott argues, when narratives of personal experience are not contextualized within existing power relationships, they function only to reproduce given ideological systems, confirming that difference exists without explaining how it is constituted. "The evidence of experience then becomes evidence for the fact of difference, rather than a way of exploring how difference is established, how it operates, how and in what ways it constitutes subjects who see and act in the world"' (Scott 1991: 777). Filtered through the ever-present logic of Orientalism, narratives of Canadian and Afghan women emerge as binary opposites, reinforcing the superiority of the former over the latter, and, as in the colonial era, the basis for Western women's status as emancipated and exemplary subjects. Emulating this inverse and simultaneous process of exaltation and subordination, ${ }^{12}$ CW4WAfghan founding member Janice Eisenhauer describes that it was not until she learned about the plight of Afghan women that she became aware of her own freedom. Reflecting on the activities that have characterized her life- "skiing and hiking in the Rockies, travelling the world and sampling a wide variety of university and college courses" (CW4WAfghan 2008c: 2)-she laments: "a girl in Afghanistan could only dream of such a day" (CW4WAfghan 2008c: 2). Other members link their own subject constitution even more directly to their involvement with

${ }^{11}$ Khan points out this approach also characterizes the Feminist Majority Foundation's campaign to "Stop Gender Apartheid in Afghanistan" - the focus of Krista Hunt's theory of embedded feminism - and briefs presented to the Senate Appropriations Committee.

12 The term "exaltation" is taken from Thobani's Exalted Subjects (2007), discussed later in this paper. 
Afghan women, describing how their work has brought them fulfillment and empowerment, and even-in an article that seems lifted from the pages of Marie Claire - gives them something interesting to talk about when being "first introduced to someone - maybe at a cocktail party, or perhaps at your spouse's workplace Christmas party" (CW4WAfghan 2008c: 5). ${ }^{13}$

While CW4WAfghan's newsletters remain rife with evidence of Afghan women's difference, increasingly, their articles discuss how CW4WAfghan members have become constituted through their likeness, rather than opposition, to their Afghan counterparts (CW4WAfghan 2008c). Accordingly, CW4WAfghan have largely replaced the spectacular images of censored faces, burqas, and bruised bodies that once donned the pages of their newsletters with pictures of well-fed children and Canadian members in hijab striking poses with their Afghan friends (see for example CW4WAfghan 1999; 2008b; 2008c). While attempting to show how "they" are really like "us", these images, and accompanying references to the "true nature" of Afghan women (CW4WAfghan 2008c:1), simply replace one static and homogenous notion of identity with another. Seemingly timeless in their strength and resilience, Afghan women inevitably remain unchanged by the power dynamics of their encounters with Canadian women, who, by contrast, constitute themselves as "vital, changing, complex, and central subjects" (Mohanty 2002: 519).

Without subverting the binary logic of us and them, CW4WAfghan's only means of displacing negative stereotypes of Afghan women as helpless victims is through positive stereotypes that align the Afghan "Other" with her modern, emancipated counterparts. In

\footnotetext{
${ }^{13}$ The self-improvement tone of such testimonies also evokes what Mohanty describes as a "modernist paradigm" of personal progress, in which "the bridge between the local and the global becomes in fact a
} 
doing so, CW4WAfghan rely on what Chandra Mohanty describes as "a cross-culturally singular, monolithic notion of patriarchy or male dominance..." (1991:53) to emphasize their similarities as women, while at the same time preserving Canadian women's emancipated status by distancing these concerns from the "real" causes of Afghan women's oppression. For example, in the latest newsletter CW4WAfghan president Carolyn Reicher writes that despite the important work done in Afghanistan by the (male) Canadian military, "in the everyday ways that count..."-cooking, cleaning, sewing, volunteering, caring for children and elders - "it is primarily the women who are doing that work. Hmmm....Does that sound familiar?" (CW4WAfghan 2008c:1) Reicher goes on to recount how, in her introduction of Dr. Sima Samar at a recent CW4WAfghan event, member Sally Armstrong

...told us how Dr. Samar (despite her many accolades, and internationally recognized role in supporting women's rights), can also make yogurt from scratch, can alter her own clothing at the drop of a hat, and can host a dinner for 10 (which she has made herself) despite having worked a full day. When Sally expressed amazement at such feats, Dr. Samar replied simply, Well, I am an Afghan woman, after all! (ibid: 4)

Not only does such rhetoric trivialize and reinforce sexual inequalities by giving them a positive spin, it also maps a homogenous notion of Western gender stereotypes onto the Other (Mohanty 1991). Linking this process to the universalizing function of imperialist ideology, Mohanty argues that by defining their oppression, "Western feminisms appropriate and 'colonize' the constitutive complexities" of third world women's lives (1991: 54), (re)producing them in their own image.

Referring to the citationary nature of Orientalism, Yegenoglu clarifies:

predominantly self-interested chasm" (Mohanty 2002: 519). 
The power of Orientalism does not stem from the 'distortion' of the 'reality' of the Orient, nor from the dissemination of 'prejudiced' or 'negative' images about other cultures and peoples, but from its power to construct the very object it speaks about and from its power to produce a regime of truth about the other (1998: 89-90).

Indeed, in their attempt to contest images of Afghan women as passive and powerless, CW4WAfghan's strategy of "giving voice" to, and promoting "positive" representations of Afghan women only add to the authority of their appropriations, reinforcing that there is a single knowable essence that defines the Afghan woman, and which it is in their power to name (CW4WAfghan 2008c: 1). 
PEDDLERS AND PEACEKEEPERS: NATIONAL NARRATIVES OF EAST AND WEST

CW4WAfghan's assumption of power-knowledge over the Orient can be seen in their construction not only of Afghan women but also of Afghanistan itself, as evidenced by "cultural events" such as the one held by CW4WAfghan last fall in Brandon Manitoba. Gayle Raynor, founder of the Military Wives Sisterhood (MWS), initiated "Afghan Awareness Week" after she learned her husband would be deployed to Afghanistan early this year. She explains: "I wanted to learn ... what is Afghanistan all about? What can I learn to better prepare and educate myself and provide answers for my children?" (Block 2007: 1) Evidently, contemporary images of bombs, burning schools, and beheaded teachers would not fit the bill—instead, CW4WAfghan dusted off the "fabulously antique and exotic" Orient of nineteenth century vintage (Said, 1978: 180):

Traditional music played in the background of a teahouse display, the smell of fresh baked naan bread and green tea with cardamon tempted your tastebuds, colourful traditional costumes and beautiful hand-made carpets dazzled your curiosity and photo slideshows depicted a country otherwise unknown to our over 1000 guests. (Block 2007: 1)

Emphasizing their success in reinvigorating and assimilating this otherwise unknown and ancient world, one military wife wrote in to thank them for "...explaining what life is really like there" and "teaching everyone what we couldn't even imagine" (Block 2007: 3). Further illustrating CW4WAfghan's authority in creating a regime of truth about Afghanistan, she concluded:

Without the partnership and guidance from CW4WAfghan, the MWS may still have been sitting in front of our computers, looking up Afghanistan and attempting to form some sense out of it. Because of you, over 1000 people have a better understanding of Afghanistan and its diverse culture (ibid). 
By appropriating apolitical, cultural elements of Afghanistan into an exotic, tantalizing spectacle, CW4WAfghan successfully constructed an Afghanistan that was palatable for its audience. "This was an Afghan Marketplace and Western Manitoba residents were eager to experience it" (ibid: 1 ; emphasis added). Purged of potentially offensive elements-religion, politics, bloodshed, resistance—CW4WAfghan's Afghanistan departs even from classic Romantic Orientalism, with its aura of terror and the macabre (Said 1978: 180). In recent travelogues, violence and struggle disappear beneath fresh pavement as CW4WAfghan members send us "rolling down smooth roads in an air-conditioned SUV, sipping mango juice and gazing at Afghanistan's striking landscape" (CW4WAfghan 2006:2). As if an analogy for their ability to select and purchase desirable elements of Afghan culture, the motif of shopping pervades such accounts. CW4WAfghan members visiting Afghanistan exhaust themselves with trips to the marketplace, evoking a "shop "til you drop" attitude, while distributing Canadian flag lapel pins to delighted vendors and spectators (CW4WAfghan 2004). Back at home, CW4WAfghan organizers encourage audiences to combat feelings of powerlessness with consumer power, offering handmade Afghan goods for purchase after a heavy lecture (see for example CW4WAfghan 2006:4). Like the flow of bodies-those returning home unscathed and bearing tales of optimism - the flow of capital ensures Afghanistan's compatibility with Western civilization, keeping the innocuous country and its women on a similar trajectory to becoming less threatening, i.e. "more like us". ${ }^{14}$

\footnotetext{
${ }^{14}$ Krista Hunt and Kim Rygiel suggest that by encouraging Afghan women to produce "'traditional' goods for the global market", Western aid agencies may be contributing to another kind of assimilation, reproducing the worldwide "feminization of poverty". For example, the US State Department's Office of International Women's Issues (OIWI) suggests a plan of economic restructuring in Afghanistan that includes training women to "weave carpets and produce traditional embroidered cloth; grow cash crops;
} 
The conflicting tropes of similitude and differentiation ${ }^{15}$ that characterize CW4WAfghan's rendering of Afghanistan as an exotic yet accessible locale correspond with two models of feminism against which Chandra Mohanty positions her work. Mohanty's feminist-as-tourist, or “in less charitable terms, the white women's burden or colonial discourse model" (Mohanty 2002: 518), is defined by a Euro-American centric approach, which sets up a binary opposition of the local self and the global Other. Her "Feminist-as-explorer" model relies on a similar process of Othering, but adopts a more contemporary, "internationalist" stance, defining both the local and global as Other so that the entire area of feminist foray is outside the Euro-American nation state (2002). While Mohanty grants that internationally-focused "feminists as explorers" can contribute to a deeper understanding of issues affecting women in certain locales, she argues that their accounts dislocate these issues from the social processes and power relationships in which Euro-American feminists are implicated. Like personal stories of Afghan women that function to individualize and decontextualize their experiences, national narratives reinforced by CW4WAfghan help preserve not only their own status as emancipated subjects, but also their national self image as benevolent helpers of women.

Arguing that Western feminist subjects are both nationalist and internationalist, Inderpal Grewal reminds us that NGOs operate outside national borders, but not outside nationalisms. Dominant notions of development and human rights, however, can help mask the national narratives they carry with them, allowing NGOs to see themselves as "the saviours of women and as being above or beyond neocolonial differences of power"

make garments; and run bakeries, all highly feminized, low-paying, and likely non-unionized work" (Hunt and Rygiel 2006: 10, fn. 7). 
(Grewal 2005: 272). Buying into this problematic notion, CW4WAfghan brand themselves as a non-political organization, issuing occasional criticisms of the Canadian government that can seem strikingly incongruent with their policies. For example, one month after posing for photos with Prime Minister Stephen Harper on International Women's Day (CW4WAfghan 2008c: 6), Vice-President Lauryn Oates professed in a public debate "there isn't a single political party in Canada I would dream of voting for" (Oates 2008). Rather than highlighting how Harper's policies are adversely affecting Afghan women, and connecting this to their failure to protect women's rights in Canada, CW4WAfghan's criticisms imply that the Canadian government is simply not doing enough for women in Afghanistan—urging them to uphold their imperial legacy, instead of recognizing the incompatibility between feminist goals and the national narratives they endorse (Oates 2006).

If gendered notions of racial and moral superiority provided legitimacy for imperial feminists' colonizing missions, Canada's national self-image of tolerance and nonracism —embodied in the role of peacekeepers—-provides equally problematic grounds for Canadian feminists' involvement in Afghanistan. Tracing the roots of Canadian national identity, Sunera Thobani describes how white European "daughters of Empire" were recruited and given special incentives to become "mothers of nation" in the newly colonized Canada, to provide a moral foundation that would help indoctrinate aboriginals and non-white migrant workers (Thobani 2007: 115-116). Drawing on Kerstin Roger's study of women psychotherapists, Thobani suggests that white women's exalted status as "civilizing pioneers" was later ensconced through their participation in the Canadian

\footnotetext{
${ }^{15}$ The concept of similitude, or sameness, as it is used here is taken from Yegenoglu (1998: 82-90).
} 
welfare state, as the "professional use of empathy became a regulatory device for social relations of difference" (Roger as cited in ibid: 126). This institutionalization and valorization of feminized qualities also signaled a shift in national identity:

Where the laissez-faire settler state had emphasized the masculinized aspects of the national subject as discoverer, conqueror, pioneer, and settler, the welfare state emphasized the feminized aspects of both state and nationals by constituting them as compassionate and caring (ibid: 108)

Like Thobani, other feminist scholars (George 2000, Srivastava 2005) suggest that these intertwined narratives of feminine and national identity not only fail to promote sexual equality, but can also lead Canadian women in "caring" professions and organizations to block out important issues such as racism, appealing instead to gendered representations of racial innocence and benevolence.

CW4WAfghan's adherence to established notions of Canadian identity and superiority is captured on the front page of a 2007 newsletter, in which a speech by Afghanistan's Minister of Education Mohammed Haneef Atmar is neatly summarized to read:

- Canada is a great nation for protecting its people, and protecting basic human rights;

- Canada is one of Afghanistan's greatest allies;

- Afghans appreciate the generosity and aid from Canada (CW4WAfghan 2007:1)

These national narratives are seamlessly mapped onto the personal narratives that help constitute the Canadian subject in CW4WAfghan's discourse. We are told that each member's story "represents a true Canadian passion for respecting diversity and equality, empowerment of women, and being actively involved in meeting our global responsibilities" (ibid)—responsibilities they tautologically define as reflecting "what it means to be Canadian" (ibid). Through CW4WAfghan's education module, discussed in 
the latter part of this paper, students learn that "as a nation of peacemakers and peacekeepers, Canada plays an important role in the Global Village protecting and promoting human rights for all people worldwide" (2008d: 2). This benign personaenforced by CW4WAfghan's consistent packaging of Canada's military presence in terms of peace-building, security, and assistance - lends legitimacy not only to the occupation of Afghanistan but also to the organization's self-image of unquestionable compassion.

The connection between CW4WAfghan's personal and national narratives, and the political agendas they support, draw attention to how story-telling as a method of knowledge-production is not only central to social movements, but also, as Foucault has demonstrated, modern modes of governance and discipline (1990). His attention to confessional practices in institutions of discipline, Christianity, and education, sheds light on the proliferation of biographies by Afghan women and women traveling in Afghanistan published after 9/11 (Whitlock 2007), as well as the current attention in the West to regulating Muslim women's bodies (Freedman 2006). Explaining how discourses of social movements and governance intersect, Inderpal Grewal describes how feminists have contributed to a particularly gendered form of governmentality in their promotion of "women's rights as human rights" discourse (2005). Grewal notes that during earlier struggles, as today, women in countries such as the US did not resort to international standards when their rights were violated, as "it was taken for granted, however erroneously, that the American legal system and others like it were adequate to the task of ensuring the rights of women" (2005: 129). In this way, international standards of human rights functioned mainly to de-legitimize nonwestern states and 
legitimize Western activism, justifying what David Chandler terms the "military humanitarianism" of George W. Bush and his allies (2001).

As Sherene Razack points out, the governmentality enforced by discourses of women's rights as human rights becomes particularly problematic when it is used to legitimize state protection of Muslim women (2007). Razack argues that in the debate over Shari'a law in Canada, feminists-Muslims and non-Muslims alikeinadvertently invoked racist and imperialist notions of difference between the white, modern, secular West, and uncivilized non-Muslim Others (2007:3). Drawing on Talal Asad, Razack demonstrates that the debate assigned the secular state a false neutrality with respect to religious minorities, ignoring —and in turn justifying - the Canadian government's propensity to regulate, monitor, and control Muslim communities (2007).

By deflecting attention away from patriarchy in their own state, Western feminists help legitimize this subordination by positing the state as neutral with respect to women's rights, and as the appropriate protector of women. While CW4WAfghan sometimes refers to similarities in patriarchy at home and in Afghanistan, they do so only to trivialize and normalize the inequalities that characterize Canadian society. For example, in a newsletter leading up to International Women's Day, Judy Miyashiro muses:

Today, Canadian women are safeguarded against systemic discrimination by the Canadian Charter of Rights and Freedoms, the Canadian Human Rights Act, and the UN's Convention on the Elimination of All Forms of Discrimination Against Women (CEDAW). And yet, Canadian women are still earning only $66 \%$ of the total after-tax income of their male counterparts; women, especially single parents and aboriginal women, continue to have higher poverty rates than men; and violence against women persists across all socio-economic strata (CW4WAfghan 2005c:2)

Rather than questioning this apparent inconsistency, she sidesteps it by emphasizing that 
Canadian women are "far luckier than many around the world who, for example, are forced to undergo the brutal disfiguration of female circumcision" (ibid). Assigning Western women unquestionable agency, she continues: "we can marry of our own volition without having to worry about incarceration or retaliatory 'honour killings.' We can envision a life for ourselves and make it so" (ibid). By implication, Afghanistan is still a dangerous place for women on account of the fact that Canadian and other international forces do not have full control of the country, and in many places "tribal laws still prevail" (CW4WAfghan 2008b: 2). Among the many issues left out of this account is how Canadian laws can be seen to oppress women, for example, by depriving First Nations women of rights traditionally granted under their own "tribal laws".

Describing the crucial role of Western feminists' power-knowledge in the completion of Orientalist discourse, Yegenoglu demonstrates how European women's travel journals provided a supplement to those of their male counterparts, allowing them to penetrate the hidden world of the harem and Oriental women (1998: 75). Similarly, Afghan Awareness Week, along with other aspects of CW4WAfghan's embeddedness, show how CW4WAfghan is not merely complicit in the phallocentric project of imperialism, but rather, essential to the completion of Canadian Orientalist discourse on Afghanistan. By erasing the politics and violence of the war on terror, CW4WAfghan paves the way for Canadian soldiers to enter the otherwise unknown/able territory, gaining the blessing of their wives and children. Giving a feminist face to the war on terror, CW4WAfghan use their privileged position as insiders to provide the Canadian government with the gendered ammunition needed to wage war in Afghanistan. Even in 
the classroom, CW4WAfghan's accounts of Afghan women act as supplement to provincial curricula, preparing Canadian children for their roles as saviours. 


\section{RE-WRITING THE WAR STORY: ALTERNATIVE NARRATIVES}

The difficulties of supporting Afghan women's struggles against oppression without affirming fixed notions of identity and Orientalist narratives presents a serious dilemma for feminists wishing to discuss women's rights in Islamic societies. As Shahnaz Khan describes in her analysis of zina (adultery) laws in Pakistan, the War on Terror's casting of Islam as inherently backwards, patriarchal, and diametrically opposed to the West has left many Muslim women feeling paralyzed when wanting to criticize misogynist practices within their own culture (Khan 2005). "Within such a paradigm", she describes, "performing a critique of the Zina Ordinance and speaking of its excesses would present a first-class sensational spectacle commanding attention as I, the authentic feminist voice of Pakistan, generate a text that appears to condemn all Pakistanis, Muslims, and other nonwhite people." (Khan 2005: 2024)

Against the paralyzing effect of dominant discourse, Khan and other selfidentifying anti-imperialist, anti-racist feminists are re-writing the War Story. Instead of rendering other women as objects of knowledge, scholars such as Joan Scott, Chandra Talpade Mohanty, and Gayatri Spivak are attempting to tell women's stories in ways that disrupt the self/other opposition of subject/object, emphasizing that identities are mutually constituted (Mohanty 2002). Their accounts assert that women's oppression in places such as Afghanistan cannot be understood within the context of East versus West, but must be placed within a context of globalization and militarization, from which their own power to speak and be heard is derived. Recognizing that their scholarship is not external to the processes of oppression and privilege being analyzed, these accounts focus on the mechanisms of power that remain hidden in order for conventional narratives to 
function, challenging the hegemony of mainstream feminist discourse in which "hierarchies between the researcher and the researched, first and third world, are frequently rendered invisible"(Khan 2005: 2027).

Drawing on examples of alternative narrative strategies developed by the feminists mentioned above, the remainder of this paper aims to see how CW4WAfghan's educational resources might contribute to an understanding of Afghanistan that challenges the parameters of Orientalist discourse prevalent in the War on Terror. One particularly useful model of analysis is Mohanty's comparative or "feminist solidarity" model of scholarship, which she presents as an alternative to the feminist-as-tourist and feminist-as-explorer approaches discussed earlier (Mohanty 2002). The solidarity model works against the homogenizing effect of Western feminist discourse by highlighting the historic, material, and sociocultural specificities of women's experiences. At the same time, it points out how these experiences are related, drawing attention to "points of connection and distance among and between communities of women marginalized and privileged along numerous local and global dimensions" (2002: 506). In contrast to the tourist-model, which sees the local as separate and different from the global, and the explorer model, which creates a new local outside the Euro-American context, this pedagogical model sees the local as part of the global, taking into consideration how connections between the two help construct social privilege and identity (ibid: 524). 


\section{CANADIAN STUDENTS AS GLOBAL CITIZENS: ORIENTALISM IN THE CLASSROOM?}

While CW4WAfghan's education kit offers a greater degree of historical and political context, and heterogeneity of narratives, than most of its resources, it falls short of providing students with a means of examining the power relationships between themselves and the Afghan people they study. In attempting to connect the local to the global, it constructs a relationship of saviours and victims that casts the two nations as distinct and wholly separate identities. As suggested in the kit's title: "Canadian Students as Global Citizens: Understanding Human Rights in Afghanistan" (CW4WAfghan 2008d) the kit emulates the process of subject/object constitution at work in their other Canadian publications, constructing "Afghan women and their families" as an object of knowledge to be rendered comprehensible (controllable), and Canadian students as subjects and protectors. ${ }^{16}$

In the first component of the program, students explore life in Afghanistan before, during, and after "the wars", through Powerpoint slides juxtaposing scenic monuments with their dilapidated counterparts (CW4WAfghan 2008d: PowerPoint slide 11). This historical primer goes beyond the "microfocus" of Taliban rule, mentioning the Soviet invasion of 1979 and even the US' support of "Afghan rebel groups" during that era (CW4WAfghan 2008d: A3). The script stops short, however, of explaining how this support would ultimately contribute to the rise of the Taliban (Rashid 2000: 176) or generating any debate regarding Canada's participation in the US-led invasion of Afghanistan in 2001. Although the discussion questions allow for some criticism of military operations in Afghanistan, these are always connected to the decision to 
"withdraw support", rather than intervene. In this way, the official War Story that sees the US and Canada as "helpers" remains intact.

By highlighting the "complications" that may arise when one country attacks another, the script deftly closes off inquiry into the ways that war may be seen as a problem in itself. Indeed, among the complications listed is the possibility that "the government that the invading country installs may be worse than the one they got rid of'(CW4WAfghan 2008d: A10) - an observation that, to very knowledgeable students, could lead to some conclusions about the US and Canada's decision to back the Northern Alliance. This path of reasoning is closed off, however, by the follow-up question: "is it right for one country to go into another, start a war, change the government and then leave?" (ibid; emphasis added)—which steers students back towards notions of responsibility and duty.

Through selective contextualization, CW4WAfghan's education kit helps to ensure that Canadians are never implicated in Afghan women's oppression. While the slide presentation and role-playing activities highlight important problems associated with war, such as landmines and the displacement of refugees, the perpetrators of the current warwith the exception of the Taliban-remain elusive. Naturalizing the recent violence in Afghanistan, the script explains that "many different countries have been fighting for control of Afghanistan for centuries", nebulously referring to the period between 1979 and 1996 as "the wars" (ibid: PP 12). Despite this violent history, 1996 is singled out as the turning point when "the Taliban took over and things changed..." (ibid: 14). This emphasis is reinforced in the second part of the program, in which students are asked to

${ }^{16}$ Adapted to fit current human rights discourse, this title evokes a similar relationship to K. M. Pannikar's Asia and Western Dominance, as described by Said (1978: 5). 
identify their assigned character's rights according to a set of cards outlining human rights in Afghanistan before, during, and "after" the Taliban (ibid: Teachers' Resource Booklet: iv). By adopting a tripartite structure that showcases the Taliban as the sole force of resistance in Afghanistan, CW4WAfghan's historical analysis reproduces the Bush administration mentality of "with us or against us", while at the same time camouflaging the 2001 invasion within a smokescreen of centuries of war.

In contrast, an historical analysis of Afghanistan built on Mohanty's model of feminist solidarity would extend a discussion of women's rights beyond the Taliban to implicate people currently in power, such as former members of the Northern Alliance, as well as the foreign leaders and groups with whom they have been allied. Students would be encouraged to think about how women and men are treated unequally in ways that often go unrecognized, including in situations of war and colonialism. Drawing on studies of gender and conflict, an alternative education would point out that women's situation has not improved since the Taliban was in power, as women in Taliban and 'post-Taliban' Afghanistan have disproportionately suffered the consequences of the War on Terror due to, for example, their restricted mobility and access to resources, and the absence of male family members (Farhoumand-Sims 2007:649). By illuminating Canada's role in the war, it would also make it clear that the ongoing challenges faced by women "even now" do not unproblematically point to continued intervention as the solution. Instead, an alternative narrative of the War on Terror would draw attention to the myriad ways in which war threatens women's well-being and security in both Canada and Afghanistan, through factors ranging from wartime domestic and sexual violence and physical displacement to loss of income, severing of familial and community ties, 
environmental destruction, and the structural effects of increased military spending (Turpin 1998; Lindsey 2001; Coomaraswamy 2005). In doing so, it would allow us to see Afghan women's oppression as a consequence of broader aspects of patriarchal domination that include, rather than simply call for, Western intervention.

The CW4WAfghan education program's discussion of human rights comes closer to Mohanty's goal of linking the local to the global, encouraging students to compare the situation in Afghanistan to historic instances of state-sanctioned discrimination in Canada. By pointing out that even today, not all people in Canada have equal access to basic human rights, this discussion moves beyond the often-flippant mentions of sexual inequalities in Canada that characterize CW4WAfghan's other discourse. Still, as "one of the best places in the world to live" (CW4WAfghan 2008d: A8), Canada remains the yardstick by which Afghanistan is measured. Powerpoint slides illustrate how "life in Afghanistan was once very much like ours", through images of women with western hairstyles and dresses, laughing and strolling down the street (ibid: PP12-13). In the interactive portion, students are asked to gauge to what degree their characters' rights have departed from their pre-war standard, and how they compare to the rights to which Canadian students currently have access (ibid: C).

Rather than engaging in a comparison that measures how peoples' lives are the same or different, better or worse, Mohanty asks us to look at how the local and global are related, and how one person's access to rights may come at the expense of another person's oppression. This type of relational analysis would not only highlight inequalities in Canada but would also allow students to link these inequalities to the oppression of women in Afghanistan, pointing out commonalities in the systems of law, 
governance, and capital that sustain patriarchy in both cases. In its discussion of the struggle for women's rights, the feminist solidarity model would also show how Afghan and Canadian women have been responding to the restraints and dangers experienced in their lives. Pointing to examples of organized activism as well as everyday resistance to patriarchal rule, it would complicate the distinction of victim/ saviour created by CW4WAfghan, while keeping in mind how, as Joan Scott points out, agency is created through situations and statuses conferred on us (1991). At the same time, it would look at some of the problems involved with NGOs and human rights rhetoric, pointing out, for example, how the War on Terror's embedding of women's rights rhetoric is thought to have strengthened opposition to women's rights in Afghanistan, positing women as perpetrators of an attack on Afghan culture and religion (Hunt 2006: 65).

In pairing its discussion of human rights with an emphasis on Canadian students' responsibilities, CW4WAfghan's educational approach rests on the assumption that "'Human Rights' is not only about having or claiming a right or a set of rights; it is also about righting wrongs, about being the dispenser of these rights" (Spivak 2005: 132). As Spivak argues, this ideology "may carry within itself the agenda of a kind of social Darwinism - the fittest must shoulder the burden of righting the wrongs of the unfit" (ibid). In response to the unequal power dynamic this creates, Spivak suggests that education should interrogate the gap between givers and receivers, "to make unstable the presupposition that the reasonable righting of wrongs is inevitably the manifest destiny of groups... and that, among the receiving groups, wrongs will inevitably proliferate with unsurprising regularity" (ibid: 145).

Instead, CW4WAfghan's unequivocal construction of Canadian students as 
saviours trivializes their own discussion of human rights in Canada, and effectively eliminates all but the "fittest" students from its discourse. Pointing out that even in Canada "many children go to school hungry, or don't have a safe place to live", (CW4WAfghan 2008d: A-8) the script nevertheless fails to consider that this may be a reality for the students in the classroom, thus ordering its audience to do their best to help these unfortunate children as well. With the goal of restoring Afghanistan to its pre-war standard where people "led lives much like ours", the show ends with two contrasting slides that represent the subject and object of its discourse. The first shows a nine-yearold girl in a Canadian classroom, who we are told has raised $\$ 750$ for teachers in Afghanistan by holding a potluck dinner. ${ }^{17}$ The caption reads: "Who Can Help?" ... "People like us!" (CW4WAfghan 2008d: PP 24). What follows is a final, wordless image of a woman in a burqa accompanied by three small children (ibid: PP 25). Like the students who do not fit into the category of being "like us"-white and privilegedthe Afghan woman's identity is reduced to being someone we must help.

As Mohanty points out, by immersing students in "area studies", the explorer perspective contributes to an understanding of issues "in discretely defined geographical and cultural spaces", while at the same time, "questions of power, agency, justice, and common criteria for critique and evaluation are silenced" (2003: 520). In the interactive portion of CW4WAfghan's education model, where students are assigned characters in proportion to the socio-economic make-up of the country, "Asif" is the one character who is financially able to leave Afghanistan when the Taliban come to power. Asif, a doctor, and his wife, a social worker, move to England, where he works in a factory and his wife

${ }^{17}$ This amount is said to represent an Afghan teacher's salary for one year. 
is a housekeeper. Even in this example, global inequalities and power relations between countries are erased. Implying that a British doctor immigrating to Afghanistan would be in a similar situation as Asif, the teacher explains "sadly, it is very difficult for professionals from other countries to gain recognition for their education and experience in their new country" (CW4WAfghan 2008d: C4). While perhaps contributing to a greater understanding of class divisions within Afghanistan, the example functions to naturalize global economic inequalities, rather than showing how the privilege of some groups is built on the oppression of others.

By masking the power dimensions that sustain systems of domination and patriarchy, "Canadian Students as Global Citizens" not only makes the War on Terror seem palatable to a younger audience, it also makes it seem manageable, enforcing the notion that ending Afghan women's oppression is a task within their reach. In the final section of CW4WAfghan's teaching module, students are encouraged to take action to help Afghan women and their families through activities ranging from fundraising to letter-writing. This emphasis on individual solutions would be significantly challenged by an alternative education model that sees oppression as the result of systemic and structural injustices caused by global power dynamics. Instead of encouraging students to write to their Prime Minister, asking him to keep his promises to Afghan women, a feminist solidarity model would bring into question whether promises of salvation are in fact worth keeping. At the same time, it would highlight local dimensions of injustice and discrimination as possible sites for action. For example, students could engage in activities that allow them to identify common stereotypes of Canadian and Afghan people, including immigrants, and work together to break down the mechanisms of power 
and discourse by which they operate. Such activities would empower students by allowing them to identify oppression—including, in some cases, their own—and learn about the processes that sustain it, rather than by enforcing national narratives that impart notions of superiority, empowering some at the expense of others. 


\section{CONCLUSION}

The alternative model outlined above is by no means exhaustive, but points to some ways that feminists can start to talk about Afghanistan and Afghan women without adhering to the oppressive restraints of the War Story, and its clean distinctions of victims and saviours, rights and responsibilities, researched and researcher. By highlighting the Canadian school system as a local site that helps perpetuate such narratives, this analysis uncovers a potential site of resistance, where feminists can put into practice the goals set out here by contesting how knowledge is constructed, staged, and reiterated in the current political climate. As has been shown, this goal cannot be separated from CW4WAfghan's goals of helping Afghan women help themselves, nor can it be achieved through a multiplication of the number of narratives -no matter how heterogeneous-that present information about Afghanistan while remaining within the Orientalist economy of dominant discourse.

Before asking whether an educational model such as this might be too difficult to realize in practice, we must consider the difficult maneuvering, the vast and delicate omissions, and the elaborate and intricate theatres needed to stage a War Story that splits the world in half, casting entire hemispheres as distinct personalities. Before questioning whether an alternative pedagogical approach, in its failure to offer easy solutions and expel guilt from national borders, might present too cruel a vision of the world for young minds, we must recognize the epistemological violence committed against students who are reduced to being the objects of teachers' discourse - students who are unable to ignore their own oppression or sell enough cupcakes to constitute themselves as compassionate subjects. Finally, we must question how a War Story that unequivocally 
casts Other women and children as victims somehow constitutes suitable and sanitary curricula for Canadian students /"global citizens".

As this paper has emphasized, these concerns cannot be considered optional for feminists discussing women's rights in Afghanistan. If Canadian women are to remain at the forefront of efforts to help Afghan women, we need to be extremely clear about our politics - including those we may inadvertently support through our discourse. Otherwise, we pursue our current endeavour at the expense of decades of feminist struggles for transnational solidarity, and alongside Orientalist narratives that (re)produce oppression under the latest and loftiest guise. 


\section{BIBLIOGRAPHY}

Block, Becky. 2007. “Afghanistan Educates Western Manitobans at Marketplace”, Canadian Women for Women in Afghanistan (newsletter). Volume 52 September/October 2007. 1,3. Accessible via: http://www.w4wafghan.ca/

Burton, Antoinette. 1992. "The White Woman's Burden: British Feminists and 'The Indian Woman', 1865-1915". Western Women and Imperialism: Complicity and Resistance. Nupur Chaudhuri and Margaret Strobel (Eds.). Bloomington and Indianapolis: Indiana University Press. 137-157.

Brunet, Ariane, Isabelle Solon Helal. 2003. "Seizing an Opportunity: Afghan Women and the Constitution-Making Process. Rights and Democracy Mission Report, May-June 2003" Montreal: International Centre for Human Rights and Democratic Development.

Butler, Judith (1993). Bodies That Matter: On the Discursive Limits of "Sex". New York: Routledge.

Canadian Council of Churches. 2008. "Communique: We Believe God Desires Peace in their Land as in Ours." January 24, 2008. Accessed at: http://www.ccccce.ca/english/home/2008/jan24_2008.htm

Chandler, David G. 2001 "The Road to Military Humanitarianism: How the Human Rights NGOs Shaped A New Humanitarian Agenda" Human Rights Quarterly (23:3). 678-700.

Cooke, Miriam. 1996. Women and the War Story. Berkeley: University of California. . 2002. "Saving Brown Women". Signs: Journal of Women in Culture and Society. $(28,1): 485-487$.

Coomaraswamy, Radhika. 2005. "Sexual Violence During Wartime". Listening to the Silences: Women and War. Helen Durham and Tracey Gurd (Eds.) Leiden: Martinus Nijhoff Publishers. 53-66.

CW4WAfghan. 2008a . "About Us". Canadian Women for Women in Afghanistan (website). Accessed at: http://www.w4wafghan.cal - 2008b. Canadian Women for Women in Afghanistan (newsletter).

Volume 54 January/February 2008. Accessible via: http://www.w4wafghan.ca/ - 2008c. Canadian Women for Women in Afghanistan (newsletter). Volume 55 March/April 2008. Accessible via: http://www.w4wafghan.ca/ - 2008d. "Canadian Students as Global Citizens: Understanding Human Rights in Afghanistan - A Teacher's Resource Kit". Accessible via: http://www.w4wafghaneducation.ca/?page=res_kit 2007. Canadian Women for Women in Afghanistan (newsletter). Volume 53 November/December 2007. Accessible via: http://www.w4wafghan.ca/ 
. 2006. Canadian Women for Women in Afghanistan (newsletter).

Volume 47 November/ December 2006. Accessible via: http://www.w4wafghan.cal . 2005a. "Annual Report: 2004/2005", Accessed:

www.w4wafghan.ca/pdf/AnnualReport2005(3mb).pdf. 1-36. . 2005b. "Afghanistan Today: Canadians as Global Citizens." Canadian

Women for Women in Afghanistan Information Bulletin. 1-12. Accessed via: http://www.w4wafghaneducation.ca/ . 2005c. Canadian Women for Women in Afghanistan (newsletter).

Volume 30, February 2005. Accessible via: http://www.w4wafghan.ca/ . 2004. Canadian Women for Women in Afghanistan (newsletter).

Volume 19, February/March 2004. Accessible via: http://www.w4wafghan.ca/ . 1999. Lifting the Veil of Silence. (information bulletin). Accessible

via: http://www.w4wafghan.cal

Farhoumand-Sims, Cheshmak. 2007. "Unfulfilled Promises: Women and peace in postTaliban Afghanistan." International Journal (Summer 2007). 643-663.

Fellows, Mary-Louise, and Sherene Razack. 1998. "The Race to Innocence: Confronting hierarchical relations among women." Journal of Gender, Race and Justice. 1(2). 335-352.

Foucault, Michel. 1990 [1978] History of Sexuality: an introduction. New York, NY: Vintage.

Freedman, Jane. "The Headscarf Debate: Muslim women in Europe and the "War on Terror."' (En)gendering the War on Terror: War Stories And Camouflaged Politics. Krista Hunt and Kim Rygiel (Eds.). Aldershot: Ashgate. 169-190.

George, Usha. "Toward anti-racism in social work in the Canadian context". Anti-racist feminism : critical race and gender studies. Agnes M Calliste, George Jerry Sefa Dei, Margarida Aguiar (eds). Halifax: Fernwood.

Glavin, Terry. 2007. "Journalist Speaks up for Afghan Women." Georgia Straight March 15, 2007. Accessed at: "http://www.straight.com/article-74969/journalistspeaks-up-for-afghan-women

Government of Canada. 2008. "Government of Canada recognizes Canadian grassroots efforts with support for Afghan women and girls". News Release, March 62008. Accessed at: http://www.canada-afghanistan.gc.ca/cippic/afghanistan/library/nr_2008_03 06a-en.asp

Grewal, Inderpal. 2005. Transnational America: Feminisms, Diasporas, Neoliberalisms. Durham \& London: Duke University Press.

Group of 78, the Canadian Peacebuilding Coordinating Committee, and the World Federalist Movement. 2008. "No Exit Strategy for Canada without Negotiations: 
Group of 78, the Canadian Peacebuilding Coordinating Committee, and the World Federalist Movement - Canada respond to Manley Panel Report." Accessed at: http://www.ploughshares.ca/libraries/Statements/Statementslist.htm

HAWCA. 2003. "Women in Mazar-e-Sharif support disarmament process." HAWCA news, October 2003. Accessed at: http://www.hawca.org/news/disarmament.htm

House of Commons debates, Official Report (Hansard) Number 053. 39th Parliament, 2nd Session. Monday, February 25, 2008. Accessed at: www2.parl.gc.ca/.../Publication.aspx?Language $=E \& M o d e=1 \&$ Parl $=39 \& S e s=2 \& D o$ cId $=3296893$

Hunt, Krista. 2006. " 'Embedded Feminism' and the War on Terror". (En)gendering the War on Terror: War Stories And Camouflaged Politics. Krista Hunt and Kim Rygiel (Eds.). Aldershot: Ashgate. 51-70.

Hunt, Krista and Kim Rygiel. 2006. "(En)Gendered War Stories and Camouflaged Politics". (En)gendering the War on Terror: War Stories And Camouflaged Politics. Krista Hunt and Kim Rygiel (Eds.). Aldershot: Ashgate. 1-26.

Khan, Shahnaz. 2005. "Reconfiguring the Native Informant: Positionality in the Global Age" Signs: Journal of Women in Culture and Society. (30, 4): 20172035. . 2001. Shahnaz Khan, "Between Here and There: Feminist Solidarity and Afghan Women", Genders, Vol 33. Online Journal, URL http://www.genders.org/

Lindsey, Charlotte. 2001. "ICRC study on the impact of armed conflict on women." International Committee of the Red Cross, Women and War. Geneva: ICRC.

Mohanty, Chandra Talpade. 2006. "US Empire and the Project of Women's Studies: Stories of citizenship, complicity and dissent". Gender, Place \& Culture (13:1). $7-20$.

. 2002. “'Under Western Eyes' Revisited: Feminist Solidarity through Anticapitalist Struggles". Signs (28:2). 499-535. .1991. "Under Western Eyes: Feminist Scholarship and Colonial Discourses". Third World Women and the Politics of Feminism. Chandra Talpade Mohanty, Ann Russo, and Lourdes Torres (Eds.). Bloomington and Indianapolis: Indiana University Press. 52-80.

Oates, Lauryn and Derrick O'Keefe. 2008. Langara Dialogues debate, proposition: "The Canadian Military Should Leave Afghanistan at Once." Wednesday, April 16, Vancouver Public Library.

Oates, Lauryn. 2007. I-Week panel probes Canada's place in Afghanistan conflict. Accessed at: http://www.gateway.ualberta.ca/view.php?aid=7494 
2006. "Afghan women still unheard". Georgia Straight. June 29, 2006.

Accessed at: http://www.straight.com/article/afghan-women-still-unheard-0?\#

RAWA. 2007. "The US and Her Fundamentalist Stooges are the Main Human Rights Violators in Afghanistan". RAWA communiqué on Universal Human Rights Day, Dec.10, 2007. Accessed at:

http://www.rawa.org/events/dec10-07 e.htm

. 2001. "Taliban should be overthrown by the uprising of Afghan nation."

RAWA statement on the US strikes on Afghanistan. Accessed at:

http://www.rawa.org/us-strikes.htm.

Rashid, Ahmed. 2000. Taliban: Militant Islam, Oil and Fundamentalism in Central Asia. Yale University Press

Razack, Sherene. 2007. "The 'Sharia Law Debate' in Ontario: The Modernity/Premodernity distinction in legal efforts to protect women from culture." Feminist Legal Studies (15) 3-32.

Reicher, Carolyn and Lauryn Oates. 2006. "Let's Help Protect Afghan Women" Calgary Herald, March 27, 2006. Accessible at:

http://209.85.173.104/search?q=cache:rXW0dak73A8J:www.readysetglobal.com/la uryn.html

Said, Edward. 1994. Culture and Imperialism. London: Vintage. . 1978. Orientalism. Harmondsworth: Penguin.

Scott, Joan. 1991. "The Evidence of Experience”. Critical Inquiry (17:4). 773-797

Spivak, Gayatri Chakravorty. 2005. "Use and Abuse of Human Rights". Boundary (2:32) 131-189. 1999. A Critique of Postcolonial Reason: Toward a History of the Vanishing Present. Cambridge and London: Harvard University Press. . 1993-1994 (1996). "Bonding in Difference: Interview with Alfred Arteaga". The Spivak Reader: Selected Works of Gayatri Chakravorty Spivak. Donna Landry and Gerald MacLean (eds.). New York: Routledge. . 1988. "Can the Subaltern Speak?" Marxism and the Interpretation of Culture. Cary Nelson and Larry Grossberg (eds.) Chicago: University of Illinois Press. 271-313.

Srivastava, Sarita. 2005. "'You're calling me a racist?' The Moral and Emotional Regulation of Antiracism and Feminism" Signs (31:1). 29-62.

Srivastava, Sarita, and Margot Francis. 2006. "The Problem of 'Authentic Experience': Storytelling in Anti-Racist and Anti-Homophobic Education". Critical Sociology, (32: 2-3). 275-307. 
Staples, Steven. 2008. "The case for more war: Panel on Afghanistan gives PM a rationale for dragging out the conflict." 24 January 2008. Accessed at:

http://www.rideauinstitute.ca/site/c.doIELOOuGnF/b.3933577/

Thobani, Sunera. 2007. Exalted Subjects: Studies in the Making of Race and Nation in Canada. Toronto: University of Toronto Press.

Valpy, Michael. 2008. "Experts comment on the report's recommendations". Globe and Mail. January 23, 2008. Accessed at:

http://www.theglobeandmail.com/servlet/story/RTGAM.20080123.wmanleystrategi sts23/BNStory/National

Turpin, Jennifer. 1998. "Many Faces: Women Confronting War" The Women and War Reader. Lois Ann Lorentzen and Jennifer E. Turpin (Eds.) New York: New York University Press. 3-18.

Whitlock, Gillian. 2007. Soft Weapons: Autobiography in Transit. Chicago: University of Chicago Press.

World Vision Canada. 2008. "CARE, Oxfam, and World Vision respond to Independent Panel Report: Afghanistan needs development that is coordinated, not co-opted". Accessed at: http://www.newswire.ca/en/releases/archive/January2008/22/c3155.html

Yegenoglu, Meyda. 1998. Colonial Fantasies: Towards a feminist reading of Orientalism. Cambridge, UK: Cambridge University Press.

York, Jodi. 1998. "The Truth About Women and Peace." The Women and War Reader. Lois Ann Lorentzen and Jennifer E. Turpin (Eds.) New York: New York University Press. 19-25.

Young, Iris Marion. 2003. "The Logic of Masculinist Protection: Reflections on the Current Security State". Signs $(29,1): 1-25$.

Zalman, Amy. 2003. "Out of the Rubble: Competing Perspectives on the lives of Afghan Women." Women's Review of Books (20:7). 1-4.

Zia-Zarifi, Sam. 2004. "Losing the Peace in Afghanistan", Human Rights Watch World Report, January, http://www.hrw.org/wr2k4/5.htm

Zine, Jasmin. 2004. "Staying on the Straight Path: A Critical Ethnography of Islamic Schooling in Ontario." Unpublished Doctoral Dissertation, Department of Sociology and Equity Studies in Education, Ontario Institute for Studies in Education/ University of Toronto. . 2006. "Between Orientalism and Fundamentalism: Muslim Women and Feminist Engagement." (En)gendering the War on Terror: War Stories And 
Camouflaged Politics. Krista Hunt and Kim Rygiel (Eds.). Aldershot: Ashgate. 2750. 